DOI https://doi.org/10.30525/978-9934-26-046-9-13

\title{
КІБЕРНЕТИЧНИЙ ПІДХІД ДО МОДЕЛЮВАННЯ НАВЧАЛЬНИХ СИСТЕМ
}

\author{
Сікора Я. Б. \\ кандидат педагогічних наук, дочент, \\ завідувач кафедри комп'ютерних наук та інформаційних технологій \\ Житомирський державний університет імені Івана Франка \\ м. Житомир, Україна
}

В період адаптивного карантину широкого поширення набули системи навчання із застосуванням комп'ютерних технологій. Для підтримки дистанційного навчання створюються різні інформаційні системи. У той же час, освітні системи з використанням комп'ютерних технологій відрізняються ступенем розподілу функцій управління між системою і користувачем, ступенем поєднання теоретичного і практичного аспектів освітнього процесу, наявності засобів контролю навчання.

Актуальність кібернетичного підходу обумовлена необхідністю ефективного управління навчальним процесом $[1,2]$. Він заснований на застосуванні принципів теорії управління і передбачає виявлення інформаційних потоків, прямих і зворотних зв'язків, аналіз способів управління, представлення різних компонентів системи у вигляді сірих і чорних ящиків [3]. Одним із завдань при проектуванні подібної системи $є$ побудова математичної моделі навчальної системи.

Аналіз літератури $[4,5]$ дозволив визначити, що до дидактичних (навчальних) систем застосовні основні принципи кібернетики:

- принцип різноманітності: керуюча система повинна мати більшу різноманітність (складність), ніж різноманітність керованої системи;

- принцип цілісності (або емерджентність): властивості дидактичної системи не зводяться до суми властивостей ії окремих елементів, а залежать від іiї структури, тому при іiї вивченні слід враховувати взаємозв'язок між елементами;

- принцип зовнішнього доповнення: управління процесом навчання вимагає коригування керуючих сигналів, які йдуть 3 теоретичної моделі;

- принцип зворотного зв'язку: в процесі навчання зворотний зв'язок реалізується при спілкуванні викладача зі студентами, спосте- 
реження за їх діяльністю на занятті, аналізі результатів усного або письмового опитування, тестування, самостійних, контрольних робіт та ін.; все це дозволяє викладачу адаптуватися до змін стану студента;

- принцип декомпозиції і ієрархії управління: система освіти складається з відносно незалежних один від одного підсистем, між якими існує певна субординація;

- принцип активного саморуху: при навчанні зменшується невизначеність знань студентів, тобто система в цілому переходить в більш впорядкований стан 3 меншою ентропією за рахунок енергії зовнішнього середовища;

- принцип цілепокладання: в процесі навчання викладач прагне збільшити кількість знань студентів при фіксованій тривалості занять так, щоб воно відповідало вимогам, що пред’являються.

3 точки зору кібернетики в моделюванні складних систем використовують кілька підходів [6]:

- модель типу «чорний ящик», яка передбачає опис вхідних параметрів системи і цілей їі роботи, при цьому невідомо, яким чином вхідні сигнали перетворюються у вихідні цілі. Дану модель доцільно реалізовувати на першому етапі моделюванні складних систем, щоб визначитися з найбільш суттєвими вхідними даними системи, а також визначити основні цілі і результати роботи системи;

- модель складових системи, яка описує всі блоки і підсистеми, що входять в систему, але не описує їх взаємодію; поділ системи на складові частини завжди визначається цілями моделювання і може бути виконано з різним ступенем деталізації. Дану модель необхідно розглядати, якщо система одночасно повинна реалізовувати кілька цілей або за реалізацію однієї мети повинні відповідати кілька різних за функціоналом блоків;

- модель структури, яка відображає взаємозв'язки між блоками або елементами системи і вказує, яким чином з вхідних даних виходять вихідні, тобто яким чином реалізуються цілі в даній системі. Дана модель передбачає наявність вже відомих вхідних і вихідних даних, а також блоків системи, які виконують певні функції.

Послідовне використання цих підходів дозволяє побудувати модель будь-якої складної системи.

Було розроблено математична модель навчальної системи, яка може бути описана наступним чином.

Математичну модель навчальної системи можна представити таким чином: 


$$
M N S=\langle O K, C, P R, P V, P S\rangle,
$$

де $O K$ - множина освітніх компонентів навчальної системи, $C-$ множина компетентностей, що формуються у студентів у результаті освоєння освітніх компонентів системи, $P R$ - множина програмних результатів навчання, сформованих у студентів в результаті освоєння освітніх компонентів системи, $P V$ - множина профілів викладачів, $P S$ - множина профілів студентів у системі.

Нехай множина освітніх компонентів:

$$
O K=\left\{O K_{i}\right\}, i=1, \ldots, n,
$$

де $O K_{i}-$ освітній компонент, який представлений кортежем

$$
O K_{i}=\left\langle C_{i}, P R_{i}, N K_{i}, T_{i}\right\rangle, \mathrm{i}=1, \ldots, \mathrm{n},
$$

де $C_{i}$ - множина компетентностей, що формуються в результаті вивчення освітнього компоненту, $P R_{i}$ - множина програмних результатів навчання, сформованих в результаті вивчення освітнього компоненту, $N K_{i}$ - навчальний контент, $T_{i}$ - засоби оцінювання.

Множина компетентностей:

$$
\mathrm{C}_{i}=\left\{c_{i j}\right\}, i=1, \ldots, n ; j=1, \ldots, m,
$$

формується в результаті вивчення $i$-го освітнього компоненту, $\epsilon$ підмножиною множини $C$ компетентностей і включає $\mathrm{c}_{i j}$ - компетентності, що формуються в процесі вивчення $i$-го освітнього компоненту, $n$ - кількість освітніх компонентів в системі, $m$ - кількість компетентностей, що формуються в процесі вивчення освітнього компоненту з номером $i$.

Множина програмних результатів навчання:

$$
P R_{i}=\left\{p r_{i j}\right\}, i=1, \ldots, n ; j=1, \ldots, m,
$$

формується в результаті вивчення $i$-го освітнього компоненту, $\epsilon$ підмножиною множини $P R$ програмних результатів і включає $p r_{i j}-$ програмні результати, що формуються в процесі вивчення $i$-го освітнього компоненту, $n$ - кількість освітніх компонентів в системі, $m-$ кількість програмних результатів, що формуються в процесі вивчення освітнього компоненту з номером $i$. Множини компетентностей і програмних результатів навчання формуються при проектуванні навчального процесу, що реалізується навчальною системою.

У ході дослідження було розглянуто принципи кібернетичного підходу, що можуть бути застосовані для моделювання навчальної 56 
системи. Запропоновано математичну модель навчальної системи, що містить множину освітніх компонентів навчальної системи, множину компетентностей, що формуються у студентів у результаті освоєння освітніх компонентів системи, множину програмних результатів навчання, сформованих у студентів в результаті освоєння освітніх компонентів системи, множину профілів викладачів та множину профілів студентів у системі. Отримана структура допоможе визначити як та якими елементами системи можна управляти в процесі освітньої діяльності.

\section{Література:}

1. Colbeck C.L., Weaver L.D., Burkum K.R. \& Bjorklund, S.A. A cybernetic systems model of teaching and research production. International Colloquium on Research and Teaching: Closing the Divide? Winchester, Hampshire, UK. March 17-19, 2004.

2. Grover V.K. Classroom Cybernetics: an Approach for Effective and Efficient Classroom Teaching. International Journal of Research in Advent Technology. 2016. Vol. 4, № 1. P. 45-52.

3. Scott B., Shurville S., Maclean P. and Cong C. Cybernetic principles for learning design. Kybernetes. 2007. Vol. 36. № 9/10. P. 1497-1514. DOI: $10.1108 / 03684920710827445$.

4. Розанова Л.В. Основы кибернетики: конспект лекций. Омск: Изд-во ОмГТУ, 2009. 60 с.

5. Майер Р.В. Кибернетическая педагогика: имитационное моделирование процесса обучения: монография. Глазов: Глазов. гос. пед. ин-т, 2014. $141 \mathrm{c.}$

6. Рыжкова М.Н. Моделирование при построении информационно-образовательных систем. Методы и устройства передачи и обработки информащии. 2014. № 16. С. 84-89. 